\title{
The performance of the Pamong Belajar in the Learning Activity Center: In the Perspective of Leadership, Organizational Culture and Achievement Motivation
}

\author{
Julduz Ruland Paus*, Harol R. Lumapow, Johanis F. Senduk, Mint Husen Raya Aditama \\ Universitas Negeri Manado, Indonesia \\ *Email: julduzpaus@unima.ac.id
}

Submitted: 19 December 2020. Revised: 31 January 2021. Accepted: 13 February 2021

\begin{abstract}
The activities and existence of SKB as an educational institution in non-formal education units are a manifestation of the achievement of good corporate governance. This study aims to describe, predict and interpret the influence of leadership, organizational culture and achievement motivation on the performance of the Pamong Belajar at the Learning Activity Center (SKB) in North Sulawesi Province. The research approach used is quantitative with survey methods, while the hypothesis testing technique used is path analysis. There were at least 100 civil servants studying at $10 \mathrm{SKB}$ and 15 districts / cities in North Sulawesi Province who were involved in this research. Research success indicators are measured based on 8 criteria contained in the Program Implementation Success Indicators (IKPP) and Institutional Success Indicators (IKK). From the results of the research analysis, it is found that the leadership characteristics of Pamong Belajar have a direct impact on organizational culture, achievement motivation and the performance of the Pamong Belajar $\mathrm{SKB}$ in North Sulawesi Province. However, there are interesting findings where achievement motivation can be a strong factor in the performance of the SKB Student Learning Association.
\end{abstract}

Key words: non-formal education, leadership, organizational culture, achievement motivation, performance

How to Cite: Paus, J. R., Lumapow, H. R., Senduk, J. F., \& Aditama, M. H. R. (2021). The performance of the Pamong Belajar in the Learning Activity Center: In the Perspective of Leadership, Organizational Culture and Achievement Motivatio. Journal of Nonformal Education, 7(1), 83-93.

DOI: http://dx.doi.org/10.15294/jne.v7i1.27848

\section{INTRODUCTION}

The study of the performance of organizations including the Learning Activities Workshop (SKB) as a Technical Implementation Unit (UPT) of the Regency / City Government in terms of serving and meeting the learning needs of the community through non-formal education pathways, becomes a must remain survival in carrying out and realizing the main tasks and functions. Therefore, performance assessment is part of Good Governance in the management of organizations", therefore if performance is not assessed, then there will be no improvement (Sobirin, 2014, pp. 1-2a).

Performance becomes an attraction that can change the environment to be more dynamic, so that the organization does not become hyper-competition. In addition, performance can be a benchmark to know the progress and development of the organization (Sobirin, 2014, pp. 6-7b). The success of an educational organization in realizing its main tasks and functions is clearly determined by a variety of determining factors, among others: (1) quantity of work, (2) quality of work, (3) job knowledge, (4) creativeness, (5) cooperation, (6) dependability, (7) initiative, and (8) personal qualities. There are several aspects of the same from the previous view, where other experts stated that the determining factors of performance are: (1) quantity, (2) quality, (3) teamwork, (4) innovation and (5) independence (Chung \& Megginson, 1981 dalamSugiyono, 2012:104-108a). Performance measurement is an important variable in management as part of efforts to improve organizational performance.

Why is the performance of SKB worthreviewing? In Law No. 20 of 2003 on National Education System 3, it is stated: "National Education serves to develop the ability and form dignified national character and civilization in order to educate the life of the nation, aiming to develop the potential of learners to become humanbeings who believe, and believe in God almighty, noble character, healthy, knowledgeable, capable, creative, independent, and becomedemocratic and responsiblecitizens". SKB is an educational institution that organizes all the duties of non-formal education. Therefore, SKB has a strategic role to provide education to people who are not able or even marginalized from formal education systems and processes. SKB also plays a role to educate the nation's life for disadvantaged people who organize equality education for students who drop out of school at elementary, junior high and high school/vocational levels.

Nationally, SKB has not succeeded in completing dropouts because there are still 4.1 million children aged 6-21 dropping out ofschool (Kawatu, 2015a). 
UNICEF data in 2016 as many as 2.5 million Indonesian children were unable to enjoy further education, namely 600 thousand elementary school age children and 1.9 million junior high school age children. In North Sulawesi Province, in 2014 there were 1,259 students who did not continue their education. The most are elementary school students as many as 416 students, junior high school 389 students, high school 173 students and vocational school 281 students (Kawatu, 2015b).

After the issuance of Perdirjen Paud and Dikmas in 2016 referred to the current year 2018 means that it has been approximately two years, observations in the field showed the performance of SKB in the sense of carrying out its duties and functions have not shown significant progress. Thus, the transfer of SKB's status of responsibility from the central government to the district/city government does not seem to be the main problem. Therefore, other efforts are needed to find, verify and find where the root of the problem is so that skb which has a central role in meeting the learning needs of the community outside the formal school system, is still not able to carry out its functions properly.

Perdirjen Paud-Dikmas number 1453 of 2016 in Chapter III has set about the indicators of the success of SKB as a similar non-formal education unit that includes Indicators of Success of Balance (CCI) and Indicators of Program Implementation Success (IKPP). Thesuccess of SKB proves that IKK and IKPP are determined by Leadership, Organizational Culture and Motivation of Pamong Learning Achievement. Leadership shapes one's attitude to being a leader who can organize his members to achieve the goals of the organization he leads. Therefore, every leader is required his ability, integrity and competence to be the driving force of his members. The particular trait carried does not affect the effectiveness or not of the leader's performance, but lies in how a leader is able to overcome every problem he or she faces. The qualities of effective leaders known as K11 are: piety, honesty, intelligence, keiklasan, simplicity, breadth of views, commitment, expertise, openness, breadth of social influence, maturity and justice. Astudy conducted by The Ohio State Leadership Study, found that leadership grows when a personbuilds a structure (Initiating Structure), and the need for recognition or importance (Husaini, 2013:319-320 a).

The achievement of a national, regional or local goal depends on the leadership of a person in an agency or organization. Cooperation with Stakeholders, the nature of leadership, will have a negative impact on the culture of the organization that prioritizes work culture and motivation to excel to produce creative-innovative works by learning pamong. The results of expert research say that effective senior leaders have: (1) knowledge relevant to products, technology, markets and people, (2) sharpness of thinking, analytical ability, strategic and multidimensio-nal thinking capacity, (3) good track record, (4) as a key player voicing the internal and external influence of institutions, (5) good interpersosnal skills, (6) energetic, highly motivated to lead and confident (Kotter, 1988 in Husaini, 2013:436b). Other experts found that the quality of the institution was determined by leadership style. The leadership style referred to is called management style by Wolking About (MBWA) (Peter and Austin (1986) in Husaini, 2008:436).

To support the advancement of education, it requires good physical, spiritual and moral aspects as well as decent socio-economic conditions of a leader (Wahab, 2008:136a). Furthermore, an education leader must meet the requirements of a humble and simple personality, helpful, patient and emotionally stable, 4. believe in yourself, 5. honest, fair and trustworthy, and have expertise in leading. Organizational leadership and culture are two words that contribute to the success or failure of an organization. The leader creates an organizational culture that will further shape his own person according to the culture embraced within the organization. Organizational culture and leadership are mutually influencegenerating connections between the two in the context of organizational life (Bass \& Avolio, 1994; Schein, 2017).

Culture serves to improve the understanding and ability of organization members in coping and living in the organization (Schein, 2004b). Organizational culture is a rule and value that can be observed and felt in an organization, organizational culture can influence the cultural behavior of its members (Schein, 2004a). For example, when we are in an organization that has high time discipline, then we will also get used to being someone who is disciplined, then the culture of discipline will crystallize into a culture. Organizational culture is more organised than mechanical. The culture cannot be created, but must be cultivated and developed. The process of forming organizational culture is due to cultural contact, cultural internalization, cultural socialization, cultural change and cultural devolution that occurs repeatedly.

With regard to the study of leadership's relationship with organizational culture can be explained as follows, organizational culture is created by leaders, while leaders are born from the existence of culture. 
Based on the perspective, the birth of culture is influenced by 3 processes, namely socio dynamic, leadership and organizational learning (Schein, 2004c). Culture influences every concept or policy that governs every program of activities created by a leader (Erwin \& Douglas, 2000). If the behavior of each member is in accordance with the standards made by the leadership then the results obtained are good. Conversely, if the behavior of members is not in accordance with the standards of the dining leader obtained unsatisfactory results. Thus, the standard value of an organizational culture is influenced by the cultural standards brought by a leader (Schein, 2004d). The theory is the same as that put forward by Greiner (1989), where an organization can develop due to the direction of the leader. However, the phenomenon can happen otherwise when the leader is present to be the successor (succession), while the culture of the previous organization has been entrenched and become part of the life of every organization in it.

In his research, Kuchinke (1999) found an interesting fact that there are different dimensions of transformational leadership, especially in charisma and the way to motivate subordinates. He further explained that several cultural values that characterize each country can affect the leadership style, but they do not make a significant difference. Employees in the US have a leadership spirit with a vision, group goals, passion for work and a desire for results. Meanwhile in Germany, workers lack charisma and initiative. The finding of leadership styles between the two countries implies that cultural values have little influence on leadership. As an example, if we are in an organization, we will find cultural differences in other organizations that we meet next. The phenomenon of organizational culture such as work ethic, discipline, cooperation, integrity, etc. is the result of organizational culture that is formed from the leadership process of its leaders and cannot be separated from each other, Schein (2004e).

In his research, Kuchinke (1999) found an interesting fact that there are different dimensions of transformational leadership, especially in charisma and ways of motivating subordinates. He further explained that several cultural values that characterize each country can affect the leadership style, but they do not make a significant difference. US workers have a leadership spirit with a vision, group goals, passion for work and a desire for outcome decisions. Meanwhile in Germany, workers lack charisma and initiative. The finding of leadership styles between the two countries implies that cultural values have little influence on leadership. An exam- ple of our environment in an organization, we will find the culture of another organization that we encounter. The phenomenon of organizational culture such as work ethic, discipline, cooperation, integrity, etc. is an organizational culture that is formed from the leadership process of its leaders and cannot share with each other Schein (2004e).

There are 6 characteristics of individuals who have high achievement motivation, namely: (1) Strong feelings of achieving goals; (2) Responsible; (3) Evaluative; (4) Full of calculation; (5) Creative and innovative; and (6) like challenges (McClelland, 1987: 77). Every characteristic that a person has will characterize each of his activities, as well as his motivation to achieve. Degeng (1997: 41) says there are 6 characteristics of achievement motivation that are commonly found in schools: (1) individuals who have high achievement motivation are involved in situations where there is a risk of failure, or prefer challenges. Conversely, individuals who have low achievement motivation tend to choose tasks that have a high chance of success, this is done to avoid feelings of anxiety. (2) internal factors have a greater influence on individual motivation to achieve. (3) prefer to complete their tasks according to their abilities, (4) they can assess the progress and achievement of their own goals (5) are visionary and look ahead. (6) does not always show a high average score in school.

Questions should be asked to answer whether Leadership, Organizational Culture and Achievement Motivation affect the SKB Student Learning Performance in North Sulawesi Province. For this reason, a field test is needed in order to obtain answers that can be accounted for scientifically through this research.

\section{METHODS}

The approach used in this research is quantitative with survey method as a way to describe data in the field and prove the influence between research variables. Quantitative research approach of influence testing is also to determine what exogenous variables are directly and significantly influential. Exogenous variables in this study are: Head leadership of SKB (X1), Organizational Culture (X2) and Motivation of Achievement (X3) that will be tested the amount of influence applied pamong Learning PERFORMANCE SKB as endogenous variables (Y), Organizational Culture (X2) and Motivation to Excel (X3). Because the nature of the proposed research hypothesis is in the form of causality hypothesis, then to test or prove the hypothesesin this study 
used a path paradigm or better known aspath analysis techniques (path analysis) with structural equations are $\mathbf{Y}=\rho \mathrm{Yx} 1 \mathrm{X} 1+\rho \mathrm{Y} \times 2 \mathrm{X} 2+\rho \mathrm{Yx} 3 \mathrm{X} 3+1+1$ +2 where $\mathrm{Y}=$ Performance Pamong Learning, $\mathrm{X} 1=$ Leadership Head SKB, X2 = Organizational Culture, X3 = MotivationAl Achievement.

Based on the formulated problems and the research objectives set, the design of this research illustrates the associative influences as follows:

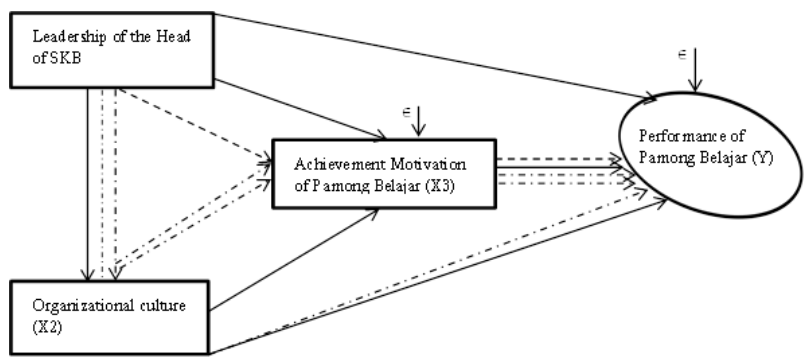

Figure 1. Research Design in the Form of Path Diagrams

A valid data contribution from this research is required which is described through the analysis of the variables of Head of SKB Leadership, Organizational Culture, Outstanding Motivation and Learning Performance. The data comes from pamong belajar population unit (PB) in all SKB in North Sulawesi Province. According to data from the Pamong Belajar Association (IPABI) of North Sulawesi Province, the number of PB in North Sulawesi Province is 148 people in 21 SKB in 15 regencies/cities. (Statistics of The State of Learning Pamong In Regency / City IPABI North Sulawesi Province Year 2017. Research Adaptation). Considering the area of North Sulawesi Province, this research uses Cluster Sampling (Area Sampling) technique. Thus, it is determined that as many as 10 (ten) SKB are considered to represent $\mathrm{pb}$ character as research respondents. Based on the determination of the number of samples from 70 populations with an error rate of $5 \%$ obtained the number of samples as many as 61 people

\section{RESULTS AND DISCUSSION}

The data description of the four research variables: Head leadership of SKB (X1), Organizational Culture (X2), Motivation of Achievement (X3 and Pamong Belajar Performance (Y) illustrates the calculation of average, median, standard deviation, minimum value and maximumvalue. Exposure to the data of the four research variables as follows:

Table 1. Research Variable Description Data

\begin{tabular}{lllll}
\hline & Variabel & & & \\
\cline { 2 - 5 } & $\mathrm{X} 1$ & $\mathrm{X} 2$ & $\mathrm{X} 3$ & $\mathrm{Y}$ \\
\hline Minimum & 57 & 67 & 75 & 81 \\
Maximum & 125 & 125 & 111 & 150 \\
Median & 99.00 & 105.00 & 96.00 & 117.00 \\
Mean & 100.25 & 104.21 & 96.69 & 120.21 \\
Std. Deviation & 10.993 & 13.614 & 7.877 & 17.379 \\
\hline
\end{tabular}

Some way of data normality testing is done with Kolmogorov-Smirnow Test, Chi-Squares Test, Lilliefors Test, or Shapiro-Wilk Test. Data normality requirement test is only done if the sample size is $n<$ 25 . If $n \geq 25$ then data normality testing is not required because the data will tend to spread according to normal distribution, according to the central limit theorem in statistics (Lasut, 2018:187). In this study the sample size was $n=61$ then the data from the five variables studied is assumed to come from a population that spreads normally. So there is no need to do normal data testing.

The regression variance variance test of the Head of SKB's Leadership on Organizational Culture was tested with the Levene test. This test result obtained statistics $=0.69$ with a value of $p=0.770$. The results of this test stated the variance of Organizational
Culture according to the observation value in the Head leadership of the SKB is the same or homogeneous because the value $p=0.770>\alpha=0.05$.

The regression variance variance test of the Head of SKB Leadership against Outstanding Motivation was tested with levene test. The result of this test was obtained statistics $=1.33$ with a value of $p=$ 0.237 . The results of this test stated that the variance of Motivation for Achievement according to the observation value in the Leadership of the Head of SKB is the same or homogeneous because the value $p=0.237>\alpha=0.05$. The organization's Cultural Regression Variance kehomogenan test against Outstanding Motivation was tested with the Levene test. This test result obtained statistics $=0.27$ with a value of $p=0.995$. The results of this test stated variance of Motivation to Excel according to observation val- 
ue in Organizational Culture is the same or homogeneous because the value $p=0.995>\alpha=0.05$. Organizational Culture regression variance kehomogenan test against Pamong Performance tested with Levene test. The result of this test was obtained statistics = 0.73 with a value of $p=0.736$. The results of this test stated that the variance of Pamong Performance according to observation value in Organizational Culture is the same or homogeneous because the value $\mathrm{p}=0.736>\alpha=0.05$.

The homogeneity test of regression variance of Outstanding Motivation to Pamong Performance was tested with Levene test. The result of this test was obtained statistics $=1.93$ with a value of $p=0.051$. The results of this test stated the variance of Pamong Performance according to the observation value on Outstanding Motivation is the same or homogeneous because the value $p=0.051>\alpha=0.05$.

From the results described earlier, briefly the homogeneity test of linear regression variance is presented in the table below (Table 2). The influence of both variables (free and dependent variables), is said to have homogeneous variance when the value $p>\alpha$ $=0.05$.

Table 2. Linear Regression Variance Variance homogen Test Results

\begin{tabular}{llll}
\hline Similarities of Variance & Levene's Test Statistics & P-Value & Conclusion \\
\hline X2 versus X1 & 0.69 & 0.770 & Homogen Variance \\
X3 versus X1 & 1.33 & 0.237 & Homogen Variance \\
X3 versus X2 & 0.27 & 0.995 & Homogen Variance \\
Y versus X1 & 0.75 & 0.711 & Homogen Variance \\
Y versus X2 & 0.73 & 0.736 & Homogen Variance \\
Y versus X3 & 1.93 & 0.051 & Homogen Variance \\
\hline
\end{tabular}

A two-variable influence linierarity test is used linear regression mismatch test through an Anava Table and scatterplotgraph. The test says both variables have a linear effect when the significance value. Linearity has $\mathrm{Sig}<0.05$ or the graph tends to be linear line.

Results of the influence test between leadership variables and Organizational Culture variables. The results shown by test $\mathrm{F}$ state that there is an influence between the Leadership variable and the Organization Culture variable in the form of a straight line (linear), because it has a value of Sig $=0.000<$ 0.05 on the Lineritas model.

The results of the influence test between the Leadership variable and the Outstanding Motivation variable. The results shown by test $\mathrm{F}$ state that there is an influence between the Leadership variable and the Achievement Motivation variable in the form of a straight line (linear), because it has a value of Sig $=0.000<0.05$ on the Lineritas model.

The results of the influence test between organizational culture variables and Outstanding Motivation variables. The results shown by test $F$ stated that there is an influence between organizational culture variable and Motivation variable in the form of straight line (linear), because it has a value of Sig = $0.000<0.05$ in the Linearity model.

The results of the influence test between the leadership variable of the Head of SKB and the variable Pamong Belajar Performance. The results shown from the $\mathrm{F}$ test state that there is an influence between the Head leadership variable of the SKB and the Pamong Belajar Performance variable in the form of a straight line (linear), because it has a value of $\mathrm{Sig}=0.018<0.05$ on the Linearity model.

The results of the influence test between the Organizational Culture variable and the Pamong Performance variable. The results shown by test $F$ state that there is an influence between the Organizational Culture variable and the Straight Line (linear) Pamong Performance variable, as it has a value of Sig $=0.000<0.05$ on the Linearity model.

The results of the influence test between the Outstanding Motivation variable and the Pamong Performance variable. The results shown by test $F$ state that there is an influence between the Organizational Culture variable and the Straight Line (linear) Pamong Performance variable, as it has a value of Sig $=0.000<0.05$ on the Linearity model.

Below is presented the results of a simple regression analysis of the influence of the 4 research variables in the form of linear influence (Table 3). The influence of both variables is said to be significant when the value of significance (Sig.) $\leq 0.05$, and is said to be insignificant whenthe value of significance (Sig.) $>0.05$.

Results of simple regression analysis in Table 3:

1. There is a strong and very significant influence between Leadership and Organizational Culture $(r=0.626$ with a value of $p<0.0001)$. 
2. There is a very strong and very significant influence between Leadership with Outstanding Motivation $(\mathrm{r}=0.643$ with a value of $\mathrm{p}<0.0001)$.

3. There is a weak but very significant influence between Leadership and Pamong Performance ( $\mathrm{r}$ $=0.310$ with a value of $p=0.008$ ).

4. There is a strong and very significant influence between Organizational Culture with Outstanding Motivation $(r=0.683$ with a value of $\mathrm{p}<$ 0.0001).
5. There is a strong and very significant influence between Organizational Culture and Pamong Performance $(\mathrm{r}=0.459$ with a value of $\mathrm{p}<$ $0.0001)$.

6. There is a weak but significant influence between Motivation to Excel and Pamong Performance $(r=0.388$ with a value of $p=0.001)$.

Table 3. Simple Regression Matrix Between Research Variables

\begin{tabular}{llll}
\hline Variable & $\begin{array}{l}\text { Culture } \\
\text { Organization }\end{array}$ & $\begin{array}{l}\text { Achievement } \\
\text { Motivation }\end{array}$ & $\begin{array}{l}\text { Pamong Belajar } \\
\text { Performance }\end{array}$ \\
\hline Leadership of the Head of & $\mathrm{r}=0,626$ & $\mathrm{r}=0,643$ & $\mathrm{r}=0,310$ \\
SKB & $(\mathrm{p}<0,0001)$ & $(\mathrm{p}<0,0001)$ & $(\mathrm{p}=0,008)$ \\
Organizational Culture & & $\mathrm{r}=0,683$ & $\mathrm{r}=0,459$ \\
& $(\mathrm{p}<0,0001)$ & $\begin{array}{l}\mathrm{p}<0,0001) \\
\mathrm{r}=0,388\end{array}$ \\
Achievement motivation & & & $(\mathrm{p}=0,001)$ \\
\hline
\end{tabular}

Based on the research hypothesis and the influence between exogenous and endogenous variables, there are six path coefficients, namely $\rho 21, \rho 32, \rho 32$, $\rho 41, \rho 42$, and $\rho 43$. To get the path coefficient, the data is analyzed using SPSS Statistics Program version 23. In this study there are three structural models that will be analyzed. The results of data analysis based on structural models in a row are presented below.

\section{Structural Model Testing 1}

The structural model 1 is as follows:

$\mathbf{X}_{2}=\rho_{\mathrm{y} 1} \mathbf{X}_{1}+$ and $_{1}$

Based on linear regression analysis obtained results as presented in Table 4 . The result in the following table is obtained the path coefficient $\rho 21=$ 0.626 with the value Sig. $<0.0001$. Graphically the effect of variable $\mathrm{X} 1$ on $\mathrm{X} 2$ according to structural model 1 . These results suggest there is a significant direct influence between $\mathrm{X} 1$ and $\mathrm{X} 2$.

Table 4. X1 Effect Path Analysis Results on X2

\begin{tabular}{lllll}
\hline Models & Regression Coefficient & Beta Coefficient & Test Value t & Significance \\
\hline Konstanta & 26.522 & & 2.092 & \\
X1 & 0.775 & 0.626 & 6.163 & Sig. $<0.0001$ \\
\hline
\end{tabular}

\section{Structural Model Testing 2}

The structural model 2 is as follows:

$\mathbf{X}_{3}=\rho_{\mathbf{y} 1} \mathbf{X}_{1}+\rho_{\mathbf{y} 2} \mathbf{X}_{2}+\mathbf{a n d}_{1}$

Based on multiple linear regression analysis obtained the result of path coefficient $\rho_{31}=0.354$ with the value Sig. $=0.003$ and the coefficient of the path $\rho_{32}=0.462$ with the value Sig. $<0.0001$. These results suggest there is a significant direct influence of $\mathrm{X} 1$ on $\mathrm{X} 3$ and there is a significant direct influence of $\mathrm{X} 2$ on $\mathrm{X} 3$.

\section{X1 and X2 Multicollinierity Check}

In the analysis of the path of examination whether or not multicoliniearity between free variables needs to be done, because it will have an impact on the influence of each free variable on dependent variables. One of the impacts will cause the influence to become insignificant or even contrary to the theory. For example, influences should be positive, but negative influences.

Multicollibility checks can be tested through $e x$ aminationofTolerance, VIF, EigenValue, Condition Index, Standard Error, simpleregression coefficient value (r), or 95\% Confidence Interval of each variable. It says there is no multicollitas when: 1) Tolerance Value $>0.1$, or 2) VIF value < 10, or 3) Eigenvalue $>0.01$, or 4$)$ Condition Index $<30$, or 5) Standard Error < 1, or 6) Regression coefficient (r) $<0.8$, or 7) $95 \%$ Confidence index is quite wide. 
Based on the results of the previous calculation of regression between free variables (X1 and X2) obtained $\mathrm{r}=0.626$ with the value Sig. $<0.0001$. Furthermore, from the results of multicollinierity examination, it turns out that from the 7 examinations presented above there is nothing to suggest that there is multicolliation between variable $\mathrm{X} 1$ to $\mathrm{X} 2$.

Table 5. Multicolearity Examination Results on Structural Model 2

\begin{tabular}{llllllll}
\hline Model & $\begin{array}{l}\text { Std. } \\
\text { Error }\end{array}$ & KI 95\% & Tolerance & VIF & Dimensions & Eigenvalue & $\begin{array}{l}\text { Condition } \\
\text { Index }\end{array}$ \\
\hline X1 & 0.094 & $0.105-458$ & 0.608 & 1.644 & 1 & 2.987 & 1.000 \\
X2 & 0.076 & $0.157-462$ & 0.608 & 1.644 & 2 & .008 & 18.961 \\
& & & & & 3 & 0.005 & 25.126 \\
\hline
\end{tabular}

\section{Structural Model Testing 3}

The structural model 3 is as follows:

$\mathbf{Y} \mathrm{y}_{1} \mathbf{X}_{1}+{ }_{\mathrm{y} 2} \mathbf{X}_{2}+{ }_{\mathrm{y} 3} \mathbf{X}_{3}+\mathbf{e}_{1}$

Based on multiple linear regression analysis obtained path coefficient $\rho_{\mathrm{y} 1}=-0.014$ with Sig value. $=$
0.932: path coefficient $\rho_{\mathrm{y} 2}=0.368$ with Sig value. $=$ 0.034 ; and path coefficient $\rho_{\mathrm{y} 3}=0.145$ with Sig value $=0.404$. Graphically the effect of variables $\mathrm{X} 1, \mathrm{X} 2$, and $\mathrm{X} 3$ on $\mathrm{Y}$ can be seen in Table 6 .

Table 6. Path Analysis Results of the Influence of X1, X2, and X3 on Y

\begin{tabular}{lllll}
\hline Model & Regression Coefficient & Beta Coefficient & Test Value t & Significance \\
\hline Konstanta & 54.063 & - & 2,611 & \\
X1 & $-0,020$ & $-0,014$ & $-0,086$ & Sig. $=0,932$ \\
X2 & 0,437 & 0,368 & 2,167 & Sig. $=0,034$ \\
X3 & 0,257 & 0,145 & 0,840 & Sig. $=0,404$ \\
\hline
\end{tabular}

\section{X1 and X2 Multicollinierity Check}

Based on the results of the previous calculation of regression between free variables $(\mathrm{X} 1, \mathrm{X} 2$, and X3) obtained $r_{12}=0.626$ with the value Sig. < 0.0001; (Table 6); $\mathrm{r}_{13}=0.462$ with the value Sig. < 0.0001 (Tabel 6); and $r_{23}=0.145$ with the value Sig. $<0.404$ (Table 6). Furthermore, from the results of multicollitas examination (Table 7), it turns outthat from the 7 examinations presented above, in Dimension 4 condition index value $=36.128>30$. This states that multi-covaririty occurs between the three free variables (X1, X2, and X3). The existence of this multicollinierity causes the path coefficient from $\mathrm{X} 1$ to $\mathrm{Y}$ to be negative, $\rho_{41}=-0.014$.

Table 7. Multicollinearity Examination Results on Structural Model 2

\begin{tabular}{llllllll}
\hline Model & $\begin{array}{l}\text { Std. } \\
\text { Error }\end{array}$ & KI 95\% & $\begin{array}{l}\text { Toler- } \\
\text { ance }\end{array}$ & VIF & Dimensions & Eigenvalue & $\begin{array}{l}\text { Condition } \\
\text { Index }\end{array}$ \\
\hline X1 & 0.238 & $-0,497-0.456$ & 0.521 & 1.918 & 1 & 3.984 & 1.000 \\
X2 & 0.202 & $0.033-0.840$ & 0.474 & 2.110 & 2 & 0.008 & 21.897 \\
X3 & 0.306 & $-0.356-0.871$ & 0.457 & 2.189 & 3 & 0.005 & 28.992 \\
& & & & & 4 & 0.003 & 36.128 \\
\hline
\end{tabular}

Based on the results in Table 7, it can be stated:

1. The effect of X1 on Y obtained the path coefficient $\rho_{\mathrm{y} 1}=-0.044$ with the value Sig. $=0.932>$ 0.05 . These results suggest there is a significant direct influence of $\mathrm{X} 1$ on $\mathrm{Y}$.

2. The effect of $X 2$ on $Y$ obtained the coefficient of the path $_{\rho 2}=0.368$ with the value Sig. $=0.034<$ 0.05 . These results suggest there is a significant direct influence of $\mathrm{X} 2$ on $\mathrm{Y}$.

3. $\mathrm{X} 3$ and $\mathrm{Y}$ influences obtained the path coefficient $\rho_{\mathrm{y} 1}=0.145$ with the value Sig. $=0.404>0.05$.
These results suggest there is no insignificant direct X3 effect on Y.

The leadership of the Head of SKB has a strategic role and determines the involvement of the people being led so that they are motivated or encouraged to carry out various activities or jobs to achieve goals together. Nurjanah (2008) in his research on the influence of leadership style and organizational culture suggests that leadership style has a positive effect on organizational culture, leadership style has a positive effect on organizational commitment, 
organizational culture has a positive effect on organizational commitment, and organizational commitment has a positive effect on employee performance. This means that the leadership style of a leader can affect the performance of employees in the organization. Leaders who have character will bring culture to the organization so that employee performance is created as expected by the leader.

Each leader in carrying out their main duties and functions can be called leadership. Leaders who are in action are what is meant by leadership to achieve organizational goals. Thus leadership can be said to be a process of directing and influencing every activity related to the work of group members (Northouse, 2016).

Future leaders are not only capable of selfidentification, able to create a shared vision for the future, and can foster close relationships with subordinates, but also must be imbued with and enriched with innovation. Innovation in the sense of can refer to new ideas that can be applied for service improvements or updates (Alifuddin, H. Moh., 2012: 8). Therefore, every educational leader should have the following characteristics: humble and simple, helpful, patient and emotionally stable, trusting in yourself, honest, fair and trustworthy, having expertise according to responsibility (Wahab, 2008: 136b ). In addition, every leader, including the head of the SKB, should have the characteristics of $\mathrm{k} 12$, namely: devotion, honesty, intelligence, sincerity, simplicity, broadness of view, commitment, expertise, openness, breadth of social influence and maturity, and justice (Husaini Usman: 2013: 322c).

Leadership models with characteristics can be studied as follows: humble and simple, helpful, patient and emotionally stable, self-confident, honest, fair and trustworthy, and expertise in position. Furthermore, it is stated that an educational leader must also have several skills, namely: skills in leadership, skills in human influence, skills in group processes, skills in personal administration, and skills in assessing (Wahab, 2008: 136-137c). Related to this, Kindervatter (1979) put forward his idea of revitalizing human resources. He is an outside education expert known for his work on Empowering Processes. With regard to leadership, it is stated about Participant leadership, namely group leadership is held by students, all activities are regulated by the group so that participants have responsibility for every activity. And in the end, a good leader will give a lot of leeway to his subordinates to work in their own way (Goleman, 2017).
Leadership is always needed at any time, both at the individual level (micro), middle level (meso) and high or broad level (macro). Leadership that is implemented and oriented towards humans generally encourages a person or group of people to be consciously motivated to do everything in order to achieve common goals.

A person or group of people who have or are classified as having high achievement motivation is clearly impossible to be born by themselves but needs an environment that is able to encourage the spirit of doing business through the implementation of leadership. Morgan \& King (1990) stated that there are several factors that influence achievement motivation, namely: (1) the behavior and characteristics of the model that is imitated by children through observational learning, (2) parents' expectations, (3) the environment and (4) the emphasis on independence. Leadership applied by a leader who spurs the achievement motivation of subordinates or employees is included in numbers one, three and four. Thus, leadership clearly has a direct influence on the achievement motivation of subordinates or employees.

Culture is born from leaders who impose their own values and assumptions on a group (Schein, 2004)). Organizational culture is always related to the leadership style in the organization, organizational culture grows and develops along with the character instilled by the leader. Leaders reflect the organizational culture of the behavior and policies they make, all of which will influence the attitudes and behavior of organizational members (Wibowo, 2016: 207209). Organizational culture is a system that is formed from values, rules and commitments that can be perceived and applied in the organization and can influence the mindsets, attitudes and behavior of members. Sidabutar, Siburian, \& Bintang, (2017) stated that there is an influence between organizational culture and student achievement motivation. Furqon (2003) found the main characteristics that can characterize the essence of organizational culture as follows: (1) Innovation and risk taking. These characteristics relate to the extent to which employees / members of the organization are encouraged to be innovative and take risks, (2) attention to detail. These characteristics relate to the extent to which employees / members of the organization are expected to display accuracy, analysis and attention to details and (3) people orientation.

Koesmono, 2017 explains that a person's behavior will affect their performance, besides that motivation 
affects job satisfaction and job satisfaction affects performance. In other words, organizational culture is a characteristic that influences management decisions in improving the performance of people in the organization. Everyone has a culture that becomes a benchmark for their hearts and minds in carrying out their activities at all times. In formal organizations, organizational culture becomes a driving force for ideas and work. In addition, organizational culture should be a driving force for the attitudes and work behavior of all parties involved in the organization concerned. This is confirmed by Prasetyo (2006) which states that there is a significant effect of achievement motivation on teacher competence.

A person's performance is determined by individual factors and external factors (Bacal, 2002; Dharma, 2005). Individual performance is influenced by expectations regarding rewards, encouragement, abilities, needs and traits, perceptions of tasks, internal and external rewards, perceptions of reward levels, and job satisfaction (Gibson et al., 1989; Rivai et al., 2005a). Every individual or group in an organization basically has a motive that encourages them to be involved in the activities of an organization in question. The statement is, whether the motive that exists within a person encourages him to work well so that the organization is successful or does the working climate in the organization encourage him to do better. Of course, the best thing is that motivation should be intrinsic (from within), even though the work climate in an organization also affects the quality of the performance of a person or group of people.

Zarvedi, Yusuf \& Ibrahim (2016) in their research on the influence of leadership, organizational culture and competence on employee performance concluded that leadership, organizational culture and competence have a direct influence on employee performance and also have an influence both directly and indirectly on organizational performance. The indirect positive effect of organizational culture on the performance of the tutors through achievement motivation can be seen from the involvement or performance of the SKB Learning Assistants in organizational program activities. Performance is a collection of the total effort that is in the worker (Griffin, 1987). Performance is the result of the multiplication of motivation and ability. These motivations and abilities influence one another (Vroom, 1964).

Suriansyah (2015) found that motivation and work ethic have a positive and significant impact on employee performance, namely $79.1 \%$ with a significance value of 0.000 . The better the motivation and work ethic, the higher the employee's performance, and vice versa if the work ethic is low, the employee's performance will also be low. Meanwhile, other research from Dhiatmik, Dantes, \& Yudana (2013) on the determination of work ethic, achievement motivation, and creativity on teacher performance found that teacher involvement in the preparation, implementation and evaluation of school programs is an effort to improve teacher work ethics. This identifies that achievement motivation should and should have an influence or influence on the performance of a person or group of people. If it turns out that achievement motivation has not or does not affect or affect performance, it means that there are variables as determinants or obstacles. In the previous description, it has been explained that individual performance is influenced by expectations regarding rewards. Another reason why this is because of the multicollinearity between the achievement motivation and the SKB tutor's performance.

Lewin (1951) in his book Field Theory in Social Science explains the power of positive and negative power. When these strengths are combined, it will form motivational strength. Movement in the field theory is observed as a result of a combination of valence and strength. Valence indicates a positive or negative result. Something that has a positive valence can cause less tension if the person gets it, but can increase tension if it is prevented from getting it. For example breakfast for a hungry person, valence does not encourage the person to move in his psychological environment, but only gives direction to movements that may arise. A movement will occur if there is a sufficiently large force pushing the person in question. Such power coordinates with need.

What has been described above can explain that achievement motivation is related to meeting one's needs. A tutor for learning whose needs cannot be met by the SKB, he will look for other institutions so that their needs are met, for example through the Community Learning Activity Center (PKBM). If PKBM does not meet its needs, it will look for other institutions until their needs are met. Although leadership, organizational culture and achievement motivation are empirically proven to influence the performance of a person or group of people, the three variables need to be empirically proven to determine other factors in a certain space and time. Particularly for the condition of the SKB Learning Community in North Sulawesi Province, it is necessary to obtain 
new findings so that they can be used as a reference in formulating future policies in the context of improvement.

It must be admitted that what has been previously described as a research result cannot be rejected and can be scientifically justified, within the scope of variables, problem formulations, research objectives, hypotheses, research methods, respondents, lists of statements, literature reviews, results of data analysis and discussion. However, if this research is carried out with the same problem formulation, research objectives, research methods, and data analysis techniques, however, it is different in terms of time and place of implementation, number of respondents, the theory used and the number of exogenous and indogeneous variables, it is likely that the results will not same.

It is recommended that this research be followed up by other parties by using more exogenous and indogeneous variables, expanding respondents and research sites so that it is not only limited to exogenous variables: Leadership of SKB Head, Organizational Culture, Achievement Motivation and endogenous variables Organizational culture, Achievement Motivation and the performance of the SKB Learning Pamong.

\section{CONCLUSION}

The evidence presented in the findings and discussion of this study leads to 4 conclusions that: (1) The characteristics of a leader directly influence the culture, motivation and performance of the Pamong Belajar. (2) Organizational culture affects achievement motivation and Pamong Belajar performance. (3) There is a significant but insignificant influence between achievement motivation on the tutor's performance. (4) there is an indirect indirect effect between: (a) SKB head leadership on tutor performance through achievement motivation, (b) SKB head leadership on tutor learning performance through achievement motivation and organizational culture, (c) there is no significant effect. direct between organizational culture and tutor performance through achievement motivation.

Achievement motivation of the tutors deserves serious attention, because it can become a barrier for tutors to achieve superior performance. Achievement Motivation should be a driving factor for a person or group to achieve personal and organizational goals. This concludes that the Pamong Belajar motivation variable should be studied more deeply why quantita- tively such facts are found. So that later achievement motivation becomes a significant positive factor supporting the performance of the SKB Learning Pamong in North Sulawesi Province, not the other way around.

\section{REFERENCES}

Alifuddin, M. H. (2012). Strategi Inovasi Peningkatan Mutu Pendidikan. Panduan Praktis Bagi Pengambil Keputusan, Pengelola dan Praktisi Pendidikan. Jakarta: MAGNA skrip Publishing.

Bacal, R. (2002). Performance Management. Jakarta: Gramedia Pustaka Utama.

Bass, B. M., \& Avolio, B. J. (1994). Transformational leadership and organizational culture. The International Journal of Public Administration, 17(3-4), 541-554.

Dhiatmik, N. A. Dantes, N., \& Yudana, I. M. (2013). Determinasi Etos Kerja, Motivasi Berprestasi, Dan Kreativitas Terhadap Kinerja Guru Di SMP Negeri Sekecamatan Sukawati. Jurnal Administrasi Pendidikan Indonesia, 4 (1), 1-10.

Danim, S. \& Suparno. (2009). Manajemen dan Kepemimpinan Transformasional Kekepala sekolahan. Visi dan Strategi Sukses Era Teknologi, Situasi Krisis, dan Internasionalisasi Pendidikan. Jakarta: Rineka Cipta.

Degeng, I. N. S. (1997). Strategi Pembelajaran, Mengorganisasi Isi dengan Model Elaborasi. Malang: Penerbitan Ikatan Profesi Teknologi Pendidikan.

Dharma, S. (2005). Manajemen Kinerja: Falsafah Teori dan Penerapannya. Yogyakarta: Pustaka Pelajar.

Erwin, J., \& Douglas, P. C. (2000). it's not difficult to change company culture. Jurnal Supervision. 61 (11), 6-11.

Furqon, C. (2003). Hakikat Komunikasi Organisasi. Bandung: UPI

Gibson, J. L., Ivancevich, J. M. \& Donnely, J. J. H. (1989). Organisasi dan Manajemen Perilaku: Perilaku, Struktur, dan Proses. Ed. 4. Jakarta: Erlangga.

Goleman, D. (2017). Leadership that gets results. In Leadership Perspectives.

Greiner, L. E. (1989). Evolution and Revolution as Organizations Grow. In Readings in Strategic Management.

Griffin, R.W. (1987). Management. Second Edition. Boston: Houhton Mifflin Press. 
Husaini, U. (2008). Manajemen: Teori, Praktik dan Riset Pendidikan. Jakarta: Bumi Aksara

Husaini U. (2013). Manajemen. Teori, Praktik dan Riset Pendidikan. Jakarta: PT. Bumi Aksara.

Kawatu, A. G. (2015). https://indonesiatimur.co/2015 /04/08/di-sulawesi-utara-1-259-siswa-terpaksaputus-sekolah/

Kindervatter, S. (1979). NonFormal Education; As an Empowering Process. New York: Printers in The United Stated of America

Kuchinke, K. P. (1999). Leadership and culture: Work-related values and leadership styles among one company's U.S. and German telecommunication employees. Journal Human Resource Development Quarterly.

Lasut. E. M. M. (2018). Pengaruh Perilaku Kepemimpinan Ketua Program Studi, Iklim Kampus dan Kualitas Pelayanan Dosen Terhadap Kepuasan dan komitmen Mahasiswa Universitas Swasta Di Provinsi Sulawesi Utara. Program Pascasarjana Universitas Negeri Manado. Disertasi Tidak Diterbitkan.

Lewin, K. (1951). Field Theory in Social Science. New York: Harper \& Row.

McClelland, D. C. (1975). The Achievement Motivation. New York: Irvington.

McClelland, D.C. (1987). Human Motivation. New York: The Press Syndicate of The University of Chambridge

Morgan, C. T. \& King, R. A. (1990). Introduction to psychology. Tokyo: Mcgraw hill.

Northouse, P. G. (2016). Leadership Theory and practice (7th ed.). Thousand Oaks, CA: SAGE Publications, Inc.

Nurjanah. (2008). Pengaruh Gaya Kepemimpinan Dan Budaya Organisasi Terhadap Komitmen Organisasi Dalam Meningkatkan Kinerja Karyawan (Studi Pada Biro Lingkup Departemen Pertanian) Program Studi Magister Manajemen Program Pasca Sarjana Universitas Diponegoro Semarang. Tesis Tidak Diterbitkan.

Prasetyo, A. (2006). Kontribusi Motivasi Berprestasi, Dan Supervisi Kepala Sekolah, Terhadap Kompetensi Guru Sekolah Dasar di Kecamatan Sumowono Kabupaten Semarang. Manajemen Pendidikan. Program Pascasar-jana. Universitas Negeri Semarang. Tesis Tidak Diterbitkan.

Rivai, V. (2003). Kepemimpinan dan Perilaku Organisasi. Jakarta: PT Raja Grafindo Persada.

Rivai, V. (2005). Performance Appraisal Sistem Yang Tepat Untuk Menilai Kerja Karyawan dan
Meningkatkan Daya Saing Perusahaan. Ed. 2. Jakarta: PT Rajagrafindo Persada.

Schein, E. H. \& Schein, P. A. (2017). Organizational Culture and Leadership (5th Ed). New Jersey: Wiley \& Sons, Inc.

Schein, E. H. (2004). Organizational Culture and Leadership ( $3 \mathrm{rd}$ ed). San Francisco: Jossey-Bass. (pp. 1-458)

Schein, E. H. (2004). Organizational Culture and Leadership. San Francisco. 18th BledCom International Public Relations Research Symposium.

Sidabutar, S. L. M., Siburian, P., \& Bintang, S. (2017). Pengaruh Budaya Organisasi, Kepuasan Kerja, dan Motivasi Berprestasi Terhadap Komitmen Organisasi Guru SMP Negeri Kecamatan Simanindo dan Kecamatan Pangururan Kabupaten Samosir. Jurnal Tabularasa.

Sobirin, A. (2014). Konsep Dasar Kinerja dan Manajemen Kinerja. Repository UT.

Sudirjo, F., \& Kristanto, T. (2015). Pengaruh Budaya Organisasi, Gaya Kepemimpinan, dan Kepuasan Kerja terhadap Kinerja Kepala Sekolah Menengah Atas di Jakarta Timur. Jurnal Manajemen Pendidikan, 1(1), 80-91.

Sugiyono. (2012). Metode Penelitian Kuantitatif, Kualitatif dan $R \& D$. Bandung: Alfabeta.

Suriansyah. (2015). Pengaruh Motivasi Dan Etos Kerja Terhadap Kinerja Pegawai Pada Sekretariat Daerah Kabupaten Kota Baru. Jurnal Ilmiah Ekonomi Bisnis. 1(1), 104-113.

Teman, K. T. K. (2017). Pengaruh Budaya Organisasi Terhadap Motivasi, Kepuasan Kerja Dan Kinerja Karyawan (Studi Pada Perusahaan Pengolahan Kayu Skala Besar di Jawa Timur). EKUITAS (Jurnal Ekonomi dan Keuangan). 10 (1).

Vroom, V. H. (1964). Work and Motivation. New York: John Wiley \& Sons.

Wahab, A. A. (2008). Anatomi Organisasi dan Kepemimpinan Pendidikan. Telaah Terhadap dan Pengelolaan Organisasi Pendidikan. Bandung: CV. Alfabeta.

Wibowo. (2016). Budaya organisasi. Sebuah Kebutuhan untuk Meningkatkan Kinerja Jangka Panjang. Jakarta: PT. Raja Grafindo Persada.

Zarvedi R., Yusuf R., \& Ibrahim M. (2016). Pengaruh Kepemimpinan, Budaya Organisasi Dan Kompetensi Terhadap Kinerja Pegawai Serta Implikasinya Pada Kinerja Sekretariat Kabupaten Pidie Jaya. Jurnal Perspektif Ekonomi Darus Salam. $2(2)$, 